\title{
Community Empowerment Through Health Promotion Regarding Prevention of the Spread of COVID-19 in East Java
}

\author{
Linda Presti Fibriana ${ }^{1}$, Nuris \\ Kushayati ${ }^{2}$, Heti Aprilin ${ }^{3}$, Anik \\ Supriani ${ }^{4}$, Nasrul Hadi \\ Purwanto 5 \\ ${ }^{1}$ Dian Husada Mojokerto Nursing \\ Academy \\ ${ }^{2}$ Dian Husada Mojokerto Nursing \\ Academy \\ ${ }^{3}$ Dian Husada Mojokerto Nursing \\ Academy \\ ${ }^{4}$ STIKES Dian Husada Mojokerto \\ ${ }^{5}$ STIKES Dian Husada \\ Mojokerto \\ Email: \\ linda.fibriana@yahoo.com
}

Received : March $2^{\text {nd }} 2021$

Accepted : May $4^{\text {th }} 2021$

Published : May $20^{\text {th }} 2021$

\section{ABSTRACT}

Organization (WHO) as a pandemic, namely a disease that is transmitted globally (global outbreak). The Covid-19 pandemic as a non-natural disaster is becoming increasingly "dangerous" if it is not addressed immediately because experts have yet to find the most effective drug and vaccine. This study aims to determine community empowerment through health promotion on preventing the spread of Covid-19 in East Java. The research method used in this research is a qualitative design. Data collection was carried out through in-depth interviews with due observance of health protocols and by using FGD (focus group discussion) on 158 participants through zoom meetings. Data were analyzed using thematic analysis. The results show that to achieve a healthy state, a person or group must be able to identify and be able to meet needs and change or control the environment. Prevent the spread of Covid-19 by washing your hands frequently with soap/hand sanitizer and applying cough etiquette. Improve health with community movements such as consumption of balanced nutrition, diligent exercise, adequate rest and frequent washing of hands with soap. It is concluded that prevention and control of the spread of Covid-19 through health promotion by empowering the community to achieve a healthy state, a person or group must be able to identify and realize aspirations, be able to meet needs and change or control the environment.

Keywords: Community empowerment, spread prevention, health promotion, covid-19

Copyright (C) 2021 IIK STRADA Indonesia All right reserved.

This is an open-acces article distributed under the terms of the Creative Commons AttributionShareAlike 4.0 International License.

\section{INTRODUCTION}

The Indonesian government has long been aggressively campaigning for the healthy paradigm in accordance with the mandate of Law Number 36 of 2009 concerning Health. In 2016, the President of the Republic of Indonesia also launched the Healthy Living Community Movement (GERMAS) to campaign for the point of view of implementing health efforts that prioritize promotive and preventive. In fact, the program that places the obligation of the community to have a healthy lifestyle was confirmed through Presidential Instruction No.1 of 2017 concerning GERMAS, and involved cross ministries and institutions. For this reason, the Directorate of Health Promotion and Community Empowerment of the Ministry of Health compiled Guidelines for Community Empowerment in Prevention of Covid-19 in RT/RW/Village, as a guide for the community to make prevention efforts by exploring the potential of the community to be empowered and able to participate and prevent Covid-19 transmission.

This is in accordance with three important points in GERMAS related to preventing the spread of Covid-19 transmission, namely increasing hygiene and healthy living habits, increasing healthy food and mproving nutrition, and increasing education on healthy living. 
Coronavirus Disease 2019 (COVID-19) is determined by the World Health Organization (WHO) as a pandemic, namely a disease that is transmitted globally (global outbreak). The Covid-19 pandemic as a non-natural disaster is becoming increasingly "dangerous" if it is not addressed immediately because experts have yet to find the most effective drug and vaccine. In Indonesia, it was first found that positive Covid-19 was found in early March 2020.

The World Health Organization (WHO) on March 11, 2020, has determined COVID-19 as a pandemic disease. Epidemiologically, the transmission spreads rapidly. In Indonesia, since the announcement of the first case, it has only taken about one month to spread to all provinces and 310 districts/cities (Kompas, 30 April 2020). Efforts are made to improve community behavior in preventing transmission of COVID-19 by increasing the development of potential capabilities, so that capacity grows to solve the problems they face. Therefore, it is necessary to have the role of individuals and society in dealing with the Covid-19 pandemic, in fact as the vanguard is the community, so community empowerment is very important through health promotion. The Covid-19 pandemic as a non-natural disaster is becoming increasingly "dangerous" if it is not addressed immediately because experts have yet to find the most effective drug and vaccine.

Data per 29 April 2020 obtained a case fatality rate (CFR) of $6.9 \%$ (Global), 8.0\% (Indonesia), 11.1\% (East Java), DKI Jakarta (9.4\%), West Sumatra (10.3\%), South Sulawesi $(8.2 \%)$ and Surabaya (14\%). In preventing the spread of Covid 19, the government and society have had a major influence on complying with health protocols. Health protocols will not run optimally if they are not supported by community participation, so an effort is needed to increase community compliance in supporting the implementation of existing protocols, but many people underestimate and ignore existing health protocols (Menkes, 2020).

The Covid 19 Handling Task Force stated that to reduce the number of positive cases and deaths, at least $75 \%$ of the population must comply with health protocols using masks (Satgas Penanganan Covid, 2020). Based on data obtained on December 3, 2020 in Indonesia, the percentage of compliance with health protocols for wearing masks was $58.32 \%$, in East Java on January 10, 2021, the percentage of compliance with health protocols for wearing masks was $<60 \%$ (Satgas Penanganan Covid, 2020).

Empowerment can be started by encouraging people to want to play a more active role in their work, to involve them in making decisions or responsibilities to complete the work. The goal to be achieved from community empowerment is to form individuals and communities to become independent. This independence includes independence to think, act and control what they do. Preventive efforts in the health protocols implemented by the community in breaking the chain of Covid-19 transmission during the New Normal period, namely by getting used to wearing masks, washing hands with soap (hand sanitizer), maintaining distance (social distancing), staying away from crowds and avoiding traveling outside. regions, especially areas that have been declared a red zone (Hamdani, 2020). Efforts are made to improve community behavior to prevent transmission of COVID-19 by increasing the development of potential capabilities, so that capacity grows to solve the problems they face. This study aims to determine community empowerment through health promotion on preventing the spread of Covid-19 in East Java.

\section{METHODS}

The research method used in this research is a qualitative design. Data collection was carried out through in-depth interviews with attention to health protocols and by using FGD (focus group discussion) and through zoom meetings with 158 participants. Data were analyzed using thematic analysis.

\section{RESULTS}

The results of this study were conducted on 158 participants. By using the FGD technique (focus group discussion) with the division of 18 participants, direct in-depth interviews were carried out by still paying attention to health protocols and 140 participants divided into eight randomly used areas based on the red zone, namely Malang Regency with 20 participants, Regency Sidoarjo with 20 participants, Jombang Regency with 20 participants, 
Kediri Regency with 20 participants, Probolinggo City with 20 participants, Pasuruan Regency with 20 participants and Surabaya City as many as 20 through zoom meetings and filling in goggle forms that had been prepared by researchers to answer 20 questions related to empowerment community about preventing the spread of COVID-19 in East Java. Health Promotion on the prevention of Covid-19 transmission, which was attended by representatives of the public.

They then actively disseminate the information to others so that the educational target becomes wider. With the implementation of community empowerment through health promotion to prevent the spread of Covid-19, it is starting to appear. Residents are increasingly disciplined in wearing masks in various community activities and keeping their distance from each other. Not only that, it is increasingly easy to find public facilities for washing hands such as in stalls, prayer rooms, posyandu and patrol posts as well as encouraging residents to become more accustomed to washing their hands using running water and soap. Other activities include improving a healthy lifestyle through the provision of thermogun and public facilities for washing hands with simple soap (CTPS) in various locations.

The residents also realize healthy food improvement and nutrition improvement through reforestation programs with family medicinal plants and fish cultivation in buckets (budikdamber). Show that to achieve a healthy state, a person or group must be able to identify and be able to meet needs and change or control the environment. Prevent the spread of Covid19 by washing your hands frequently with soap/hand sanitizer and applying cough etiquette. Improve health with community movements such as consumption of balanced nutrition, diligent exercise, adequate rest and frequent washing of hands with soap. The support of stakeholders and community leaders is very important in fighting Covid-19. The Director of Health Promotion and Community Empowerment remembers not to forget to keep running 3M, stay calm and think positively, and be diligent in exercising and maintaining a healthy body.

\section{Community Movement}

To support the realization of a community that is willing and able to maintain and improve their health as stated in this vision of health promotion, within the community itself there must be movements or activities for health. Therefore, health promotion must encourage and spur activities in the community in realizing their health. Without community activities in the health sector, behavior that is conducive to health or people who are willing and able to maintain and improve their health such as wearing masks in various community activities and keeping distance from each other, easy to find public facilities for washing hands such as in stalls, prayer rooms, posyandu and guard posts, encouraging residents to become more accustomed to washing their hands using running water and soap. Another community movement by increasing healthy lifestyles through the provision of thermogun and public facilities for washing hands with simple soap (CTPS) in various locations.

\section{Individual skills (Personnel Skill) or the ability to meet needs}

Increasing skills in maintaining and improving public health is by providing insights to community members about ways to maintain health, prevent disease, recognize disease, seek treatment at professional health facilities, improve health, and so on. The methods and techniques for providing understanding are more individual than mass, such as washing hands properly with soap and running water, wearing the correct mask, doing activities with a minimum distance of 1-2 meters or avoiding crowds to prevent the spread of COVID-19.

\section{Enabling environment (Supportive Environment) or Changing and Controlling the Environment}

This strategy is aimed at managers of public places, including city or district governments in East Java, so that they provide infrastructure or facilities that support the creation of healthy behavior for the community, or at least comply with health protocols. One of them is a supportive environment to break the chain of the spread of COVID-19 by providing public facilities for washing hands such as in shopping or malls, people's markets, stalls, prayer rooms, health service places, posyandu and patrol posts and other public places. 


\section{Reorientation Health Service}

Understanding that the community is not only a user or recipient of health services, but also an organizer, within certain limits. The realization of the reontality of health services is that health service providers, both government and private, must involve, even empower the community so that they can also play a role not only as recipients of health services, but also as health service providers. In orienting health services, the role of health promotion is very important.

\section{Health Public Policy}

Health promotion strategies aimed at policy makers or policy makers so that they issue public policies that support or benefit health. With policies in the form of regulations, laws, decrees and so on, always have a public health perspective or orientation. One of them is the existence of regulations or laws that regulate the existence of an environmental impact analysis due to the Covid-19 pandemic in every policy issued by public officials, must pay attention to the impact on the environment (public health) such as the lock down policy with data from the Covid-19 task force Covid-19, traveling abroad, requiring residents to carry out rapid tests if they leave the red zone.

\section{CONCLUSION}

That the prevention and control of the spread of Covid-19 through health promotion by empowering the community to achieve a healthy state, a person or group must be able to identify and realize aspirations, be able to meet needs and change or control the environment. A community empowerment innovation that is able to reduce epidemiological indicators, such as morbidity, mortality and transmission rates

\section{REFERENCE}

Hamdani. (2020). Social Compliance in the New Normal Era. Accessed on January 16, 2021 from https://www.ajnn.net/news/kepatuhansocial-di-era-new-normal/index.html

Ian \& Marcus (2011). Health Psychology Complete and Comprehensive Guide to Health Psychology Studies. Mold I. Yogyakarta: Palmall.

Kementerian Kesehatan RI (2020). Guidelines for Prevention and Control of Corona Virus Disease (Covid-19) 5th Revision. RI Ministry of Health. Jakarta.

Kemenkes RI. (2020). Health Protocols for Communities in Public Places and Facilities. Accessed on January 16, 2021 from https://covid19.kemkes.go.id/protokolcovid19/protokol-kkes-bagimasyarakat-di-tempat-dan-Facilities-umum-dalam-rangka-penanggancovid-19/\#.XzzrJ-gzbDc

Kemenkes RI. 2020. Preparedness for COVID-19 infection. Accessed on 18 January 2021 from https://www.kemkes.go.id/article/view/20092200001/kemenkes-s Saran-3-jenis-maskeruntuk-dipakai.html

Kemenkes RI. 2020. Decree of the Minister of Health of the Republic of Indonesia regarding public health protocols. Accessed on January 18, 2021 from https://promkes.kemkes.go.id/kmk-no-hk0107-menkes-382-2020-tentang-protokol-kkes-bagi-masyarakat-ditempat-dan-f Facilitiesumum- in the context of-prevention-covid19

Notoatmojo. 2010. Health Promotion Theory and Applications. Jakarta: Rineka Cipta Kozier. (2010). Nursing Fundamental Textbook: Jakarta: EGC.

Pennington, Tess. (2020). Guidelines for Preparedness for Facing Corona Virus. Jakarta: PT Elex Media Komputindo. 
Purnamasari and Anisa. (2020). Level of Knowledge and Behavior of Wonosobo Regency Communities About Covid-19. Accessed on January 16, 2021 from https://ojs.unsiq.ac.id/index.php/jik/art icle / view / 1311 / 783Rosa. 2018.

Sari, Nabila, and Atiqoh (2020). The Relationship Between Public Knowledge and Compliance with the Use of Masks as an Effort to Prevent Covid-19 in Ngronggah. Accessed on January 16, 2021 from http://ojs.udb.ac.id/index.php/infokes/article/view/850

Satuan Tugas (Satgas) Penanganan COVID-19. 2020. Accessed on January 16, 2021 from https://covid19.go.id/p/berita/kepatuhan-masyarakat-terhadap-protokol-keseh-harus-dit Enhanced

Satuan Tugas (Satgas) Penanganan COVID-19. 2020. General Guidelines for Facing the Covid19 Pandemic for Local Governments for Prevention, Control, Diagnosis and Management. 2020. Jakarta: Ministry of Home Affairs

WHO. (2020). Novel Corona Virus. Accessed on January 16, 2021 from https://www.who.int/indonesia/news/novel coronavirus / qa-for-public

WHO. 2020. Recommendations regarding the use of masks in the context of COVID-19. Accessed on 18 January 2021 from https://www.who.int/docs/defaultsource/searo/indonesia/covid19/anjuran-mengenai-peng]-masker-dalam-konteks-covid19-june-20.pdf? sfvrsn $=$ d1327a85_2 